\title{
Evidence that polygenic risk for psychotic disorder is expressed in the domain of neurodevelopment, emotion regulation and attribution of salience
}

\author{
J. van $\mathrm{Os}^{1,2 *}$, Y. van der Steen ${ }^{1}$, Md. A. Islam ${ }^{3}$, S. Gülöksüz ${ }^{1}$, B. P. Rutten ${ }^{1}$, C. J. Simons ${ }^{1,4}$ and \\ GROUP Investigatorst \\ ${ }^{1}$ Department of Psychiatry and Psychology, Maastricht University Medical Centre, Maastricht, The Netherlands \\ ${ }^{2}$ Department of Psychosis Studies, King's College London, King's Health Partners, Institute of Psychiatry, London, UK \\ ${ }^{3}$ University of Groningen, University Medical Center Groningen, University Center for Psychiatry, Groningen, The Netherlands \\ ${ }^{4}$ GGzE, Institute for Mental Health Care Eindhoven and De Kempen, Eindhoven, The Netherlands
}

Background. The liability-threshold model of psychosis risk predicts stronger phenotypic manifestation of the polygenic risk score (PRS) in the healthy relatives of patients, as compared with healthy comparison subjects.

\begin{abstract}
Methods. First-degree relatives of patients with psychotic disorder (871 siblings and 812 parents) and healthy comparison subjects $(n=523)$ were interviewed three times in 6 years. Repeated measures of two psychosis phenotypes, the Community Assessment of Psychic Experiences (CAPE; self-report-subscales of positive, negative and depressive symptoms) and the Structured Interview for Schizotypy - Revised (SIS-R; clinical interview - subscales of positive and negative schizotypy), were examined for association with PRS. Interview-based lifetime rate of depressive and manic episodes were also examined, as was association with repeated measures of intelligence quotient (IQ).
\end{abstract}

Results. In the relatives, PRS was associated with CAPE/SIS-R total score (respectively, $B=0.12,95 \%$ CI $0.02-0.22$ and $B=0.11,95 \%$ CI $0.02-0.20)$, the SIS-R positive subscale $(B=0.16,95 \%$ CI $0.04-0.28)$, the CAPE depression subscale ( $B=0.21,95 \%$ CI $0.07-0.34$ ), any lifetime affective episode (OR 3.1, 95\% CI 1.04-9.3), but not with IQ ( $B=-1.8,95 \%$ $\mathrm{CI}-8.0$ to 4.4$)$. In the controls, similar associations were apparent between PRS on the one hand and SIS-R total score, SIS-R positive, SIS-R negative, any lifetime affective episode and, in contrast, lower IQ $(B=-8.5,95 \%$ CI -15.5 to -1.6$)$.

Conclusions. In non-ill people, polygenic risk for psychotic disorder is expressed pleiotropically in the domain of neurodevelopment, emotion regulation and attribution of salience. In subjects at elevated genetic risk, emerging expression of neurodevelopmental alterations may create floor effects, obscuring genetic associations.

Received 14 September 2016; Revised 15 March 2017; Accepted 16 March 2017

Key words: Depression, genetics, neurodevelopment, schizophrenia.

\section{Introduction}

There is strong evidence that measures of psychosis proneness in non-clinical populations are associated with a family history of psychotic disorder (Linscott \& van Os, 2013; Jeppesen et al. 2015). However, early reports on associations between measures of psychosis proneness in the general population and genome-wide association study (GWAS)-based polygenic risk scores (PRS) for schizophrenia (International Schizophrenia et al. 2009; Iyegbe et al. 2014) are inconclusive (Sieradzka et al. 2014; Zammit et al. 2014; Jones et al. 2016; van

* Address for correspondence: J. van Os, Department of Psychiatry, Brain Center Rudolf Magnus, University Medical Centre Utrecht, Heidelberglaan 100, Utrecht, the Netherlands.

(Email: vanosj@gmail.com)

† See Appendix.
Os, 2016). Any association between psychosis proneness and PRS may be stronger in relatives of patients, compared with the general population, given that expression of psychosis-related phenotypes likely is attributable to genes shared with the patient relative (Kendler et al. 1993; Cardno et al. 1999), whereas expression of psychosis-related phenotypes in general population samples may be associated more with environmental effects (Van Os et al. 2010; Linscott \& van Os, 2013; Svrakic et al. 2013). We therefore hypothesized that the link between PRS and expression of psychosis phenotypes would be stronger in relatives of patients, who share liability genes with their ill relative, as compared with the general population, whose level of genetic liability is much lower.

Data pertained to patients with psychotic disorder $(n=1119)$, their parents $(n=920)$ and siblings $(n=$ 1059) and healthy comparison subjects $(n=586)$ 
participating in the baseline, 3-year and 6-year follow-up assessments of the Genetic Risk and Outcome of Psychosis (GROUP) study. Repeated measures of two psychosis phenotypes, indexed with the Community Assessment of Psychic Experiences (CAPE; self-report) and the Structured Interview for Schizotypy - Revised (SIS-R; clinical interview), were examined for association with PRS. Given strong associations between psychosis phenotypes and measures of affective dysregulation (Verdoux et al. 1999; Hanssen et al. 2003; Van Rossum et al. 2011; Varghese et al. 2011; Wigman et al. 2012; Stochl et al. 2015), affective outcomes were also included in the analyses. Given the commonly hypothesized notion that genetic effects in schizophrenia are mediated through altered neurodevelopment (Hubbard et al. 2016), neurocognition was also examined in relation to PRS.

\section{Methods \\ GROUP study}

Full details of the GROUP study have been presented elsewhere (Steinberg et al. 2011; Korver et al. 2012). In representative geographical areas in the Netherlands and Belgium, patients were identified through clinicians working in regional psychotic disorder services, whose caseload was screened for inclusion criteria. Subsequently, a group of patients presenting at these services either as out-patients or in-patients were recruited for the study. Healthy comparison subjects were selected through random mailings to addresses in the catchment areas of the cases. The GROUP study was not conducted in a geographically well-defined small area, as it in fact included the majority of mental health services in the Netherlands, and a substantial part of mental health services in Dutch-speaking Belgium. Healthy comparison subjects could not be representative in all aspects, as an exclusion criterion was absence of a family history of psychotic disorder. The goal was to collect a group of healthy comparison subjects that (i) was collected from the same geographical area as the case in the relevant mental health service, (ii) was sufficiently large to allow for chance variation and (iii) was frequency-matched in age- and sex distribution to the siblings and (iv) had absence of family history of psychotic disorder. Table 1 shows that healthy comparison subjects, siblings and parents had similar sex distributions whilst healthy comparison subjects and siblings did not have large differences in age.

\section{Sample}

The full GROUP sample at baseline consisted of 1119 patients with non-affective psychotic disorder, 1059 siblings of these patients, 920 parents of the patients and 586 unrelated healthy comparison subjects. Inclusion criteria were: (i) age range $16-50$ years and (ii) good command of Dutch language. For patients, an additional inclusion criterion was the presence of a clinical diagnosis of non-affective psychotic disorder. Healthy comparison subjects status was confirmed by using the Family Interview for Genetic studies (NIMH.Genetics.Initiative, 1992) with the healthy comparison subject as informant, to establish absence of first degree relatives with a psychotic disorder. Diagnosis was based on the Diagnostic and Statistical Manual of Mental Disorder-IV (DSM-IV) criteria (American Psychiatric Association, 2000), assessed with the Comprehensive Assessment of Symptoms and History (CASH) interview (Andreasen et al. 1992) or Schedules for Clinical Assessment for Neuropsychiatry (SCAN 2.1) (Wing et al. 1990). The majority of patients had a DSM-IV diagnosis of schizophrenia (DSM-IV 295. $\mathrm{x} ; n=940,84 \%$ ). In the sibling and healthy comparison subject groups, there were respectively, 154 (14\%) and 59 participants $(10 \%)$ with a history of a common mental disorder at baseline, the majority of whom had a mood disorder (DSM-IV 296.x).

The study was approved by the standing ethics committee, and all the subjects gave written informed consent in accordance with the committee's guidelines.

\section{Sample for analysis}

For the purpose of the current analyses, siblings, parents and healthy comparison subjects groups were included. Analyses were restricted to the European white ethnic group $(n=2218$, or $87 \%$ out of a total of 2565 siblings, parents and healthy comparison subjects groups at baseline) given the fact that prevalence of risk alleles varies widely across ethnic groups, as may the risk associated with individual alleles, and evidence exists of differential effects of PRS across ethnic groups (Marden et al. 2014). Observations of siblings and healthy comparison subjects who made a possible ( $n=2$, of whom 1 of European white ethnic group) or definite $(n=16$, of whom 11 of European white ethnic group) transition to a psychotic disorder over the follow-up period, and thus were re-classified as patients, were excluded from analysis. Applying ethnicity and transition criteria thus resulted in a baseline sample of 523 healthy comparison subjects, 871 siblings and 812 parents of siblings (total sample: $n=2206$ ). Of the 2206, the number of individuals with data permitting calculation of the PRS was 1578 (72\%) with approximately equal proportions across healthy comparison subjects $(73 \%)$, siblings $(67 \%)$ and parents $(75 \%)$.

\section{SIS-R}

The SIS-R was administered to healthy comparison subjects, parents and siblings. The SIS-R is a semi- 
Table 1. Baseline demographics of GROUP participants in current analysis

\begin{tabular}{|c|c|c|c|c|c|c|c|c|c|c|}
\hline & \multicolumn{2}{|l|}{ Age } & \multirow[b]{2}{*}{$\%$ Female } & \multicolumn{2}{|c|}{ Education $^{\mathrm{a}}$} & \multicolumn{2}{|l|}{ IQ } & \multicolumn{2}{|c|}{$\begin{array}{l}\text { Urbanicity at } \\
\text { birth }^{\text {b }}\end{array}$} & \multirow[b]{2}{*}{$N$} \\
\hline & Mean & S.D. & & Mean & S.D. & Mean & S.D. & Mean & S.D. & \\
\hline Healthy comparison subjects & 31.10 & 10.70 & 0.55 & 2.95 & 1.27 & 110.16 & 14.79 & 2.57 & 1.68 & 523 \\
\hline Sibs & 27.85 & 8.32 & 0.53 & 2.63 & 1.48 & 104.00 & 15.22 & 2.52 & 1.63 & 871 \\
\hline Parents & 54.83 & 6.83 & 0.57 & 2.53 & 1.57 & 103.54 & 16.68 & 2.26 & 1.58 & 812 \\
\hline Total & 38.55 & 15.08 & 0.55 & 2.69 & 1.46 & 105.31 & 15.90 & 2.51 & 1.64 & 2206 \\
\hline
\end{tabular}

${ }^{a}$ Education (Verhage): range 0 (no education), 3-5 (school diploma) to 8 (university degree).

${ }^{\mathrm{b}}$ Urbanicity: $1=<500 / \mathrm{km}^{2} ; 2=500-1000 / \mathrm{km}^{2} ; 3=1000-1500 / \mathrm{km}^{2} ; 4=1500-2500 / \mathrm{km}^{2} ; 5=2500+/ \mathrm{km}^{2}$.

structured interview containing 20 schizotypal symptoms and 11 schizotypal signs rated on a 4-point scale (Kendler et al. 1989; Vollema \& Ormel, 2000). Symptoms are defined as verbal responses to standardized questions concerning, for example, magical ideation, illusions and referential thinking. Signs refer to behaviours that are rated by the interviewer such as goal directedness of thinking and flatness of affect. Questions and rating procedures are standardized. Guided by previous research, 33 item scores were reduced a priori to two-dimensional scores, representing the means of seven positive schizotypy items (covering the areas of referential thinking, psychotic phenomena, derealisation, magical ideation, illusions and suspiciousness) and eight negative-disorganized schizotypy items (covering the areas of social isolation, sensitivity, introversion, restricted affect, disturbances in associative and goal-directed thinking, poverty of speech and eccentric behaviour).

\section{CAPE}

The CAPE (www.cape42.homestead.com) was developed in order to rate self-reports of lifetime psychotic experiences (Konings et al. 2006). Items are modelled on patient experiences as contained in the Present State Examination, 9th version (Wing et al. 1974), schedules assessing negative symptoms such as the Scale for the Assessment of Negative Symptoms (SANS) (Andreasen, 1982) and the Subjective Experience of Negative Symptoms (SENS) (Selten et al. 1993) and scales assessing depressive symptoms such as the Calgary Depression Scale (Addington et al. 1993). Items are scored on a 4-point scale. In the current analyses, CAPE dimensions of frequency of positive experiences (20 items), negative experiences (14 items) and depressive experiences (eight items) were included (measured at baseline and 3- and 6-year follow-up), representing the person's perceived psychosis load over the lifetime (at baseline) or in the past 3 years (follow-up). A total score representing the mean of all items was calculated for each dimension.

\section{Manic and depressive episodes}

Lifetime rate of depressive and manic episodes were derived from the CASH interview (data available for 3 of the 4 centres).

\section{Intelligence quotient (IQ)}

At baseline and 3-year follow-=up, IQ was estimated based on the four-subtest version (Information, Block Design, Digit Symbol Coding and Arithmetic) (Blyler et al. 2000) of the Wechsler Adult Intelligence Scale (WAIS-III) (Wechsler, 1997). At 6-year follow-up, IQ was estimated based on a short version of the WAIS-III short form: the Digit Symbol Coding subtest, uneven items of the Arithmetic subtest, uneven items of the Block Design subtest, every third item of the Information subtest (Velthorst et al. 2013).

\section{Follow-up}

Healthy comparison subjects and siblings were eligible for follow-up; parents were only assessed at baseline. Of the 523 healthy comparison subjects and 871 siblings at baseline, $80 \%(n=1115)$ were assessed at 3-year follow-up (healthy comparison subjects: 79\%, $n=415$; siblings: $80 \%, n=700)$ and $69 \%(n=973)$ at 6-year follow-up (healthy comparison subjects: $68 \%, n=357$; siblings: $71 \%, n=616$ ). Ratings of CASH, SCAN, SIS-R and CAPE at follow-up reflected the period between baseline and first follow-up, and between first and second follow-up, respectively. Mean time to first follow-up was 3.3 years (s.D. $=0.5$ ) and mean between first and second follow-up was 3.1 years (S.D. $=0.4$ ).

\section{Genotyping, imputation and PRS}

Genotyping was performed using two platforms. A total of 1434 participants (758 patients, 676 healthy 
comparison subjects) were genotyped on the Illumina platform for 547383 SNPs on the Illumina HumanHap 550k v3.0 beadchip. A second group of 1968 participants (393 patients, 154 controls and 1421 healthy relatives) were genotyped for 929556 SNPs using the Affymetrix genome-wide Human SNP Array version 6.0.

A binary data set of the Illumina platform was generated including 547383 genotyped variants in 1434 subjects. We excluded 36 samples showing a sex mismatch between recorded and the genetically determined gender type, leaving 1,398 people for further analysis. We excluded SNPs that were haploid or had missing rates per SNP of $>0.10$, or a MAF of $<0.01$ or a HWE $p$ value $<0.00001$ (in healthy comparison subjects) and excluded individuals, with a missing rate $>10 \%$, altogether yielding 515286 variants and 1393 individuals (737 patients and 656 healthy comparison subjects) for further analysis. Next, a binary data set of Affymetrix platform was generated including 929 556 SNPs genotyped in 1968 subjects (393 patients and 1575 relatives), of which 729597 SNPs and 1968 individuals passed the standard quality processing checks. We successfully converted genetic coordination of all variants (except for 57 from Illumina and 86 from Affymetrix) from Human NCBI36/hg18 to GRCh37/ hg19 using Liftover (online tools) for all samples. Next, we imputed both platform samples on the backbone of $1000 \mathrm{G}$ Phase-3 reference haploblocks, as implemented in the Haplotype Reference Consortium (HRC) (McCarthy et al. 2016), using the Michigan Imputation Server and the SHAPEIT option for phasing. This yielded 46178415 imputed variants, which was reduced to 16353433 SNPs after selecting SNPs with a quality score (info score) threshold of $>0.30$, of which 9067392 variants and 1393 subjects passed the post-imputation QC. As for Affymetrix genotypes, 1kG-based imputation yielded 46178419 imputed SNPs, which were reduced to 9122501 SNPs after implementing post-imputation quality controls in 1968 subjects. These were included in the next step.

In order to calculate PRS, we obtained summary statistics of the genome-wide association study from the Psychiatric Genomic Consortium-2 (PGC2) (Schizophrenia Working Group of the Psychiatric Genomics, 2014), which included the GROUP subjects. We performed meta-analysis again while excluding GROUP samples as well as other Dutch samples, including a total of 17104566 SNPs, of which 8242 976 SNPs were common with imputed GROUP genotypes from Illumina-based variants and 8290712 variant from Affymetrix-based variants. Following the approach taken by the international psychiatric GWAS consortium, we calculated a PRS at the metagwas p-threshold of $<0.1$ for association with
Schizophrenia by PGC2. This included 2302038 SNPs of which 1481064 SNPs were common with the Illumina genotype dataset, and 1483770 SNPs were common with the Affymetrix genotype data set (1 455047 SNPs are common across both platforms). Furthermore, we repeated our association analysis at p-threshold of $<0.01$, which constituted 449794 SNPs (364 121common with the Illumina platform, 363 305common with the Affymetrix platform and 360 150 SNPs common across both platforms). We used PRSice (Euesden et al. 2015) software to calculate PRS; by LD clumping of $r 2$ value $<0.2$, at distance threshold of $250 \mathrm{~kb}$, while adjusting for 10 eigenvectors calculated by Eigenstrat (Price et al. 2006). This led to inclusion of 119653 SNPs from the Illumina platform and 119271 SNPs from Affymetrix for estimating PRS at p-metagwas $<0.1$; and 25250 SNPs from the Illumina and 25152 SNPs from the Affymetrix platform to estimate PRS at $p$-metagwas $<0.01$. We calculated different PRS using different $p$ value thresholds, from 0 to 0.50 , and checked the explained variances at the different threshold of PRS on schizophrenia using Nagelkerke's R-square. The analyses are based on the p-threshold of 0.01 with sensitivity analyses for the p-threshold of 0.1 . For ease of interpretation, a constant was added to the two PRS scores, so that the minimum value was 0 .

\section{Analyses}

GROUP database version 5.0 was used for all analyses. Random intercept multilevel regression models (given clustering of individuals within families as well as clustering of repeated measures within subjects) with SIS-R and CAPE measures as dependent variables were fitted using the MIXED routine in the Stata program, version 14 (StataCorp, 2015). Independent variables were PRS, a priori corrected for age and sex. In addition, binary outcomes of CASH lifetime depressive and manic episode were modelled using the Stata MEQRLOGIT multilevel random intercept logistic regression routine, similarly adjusted for age and sex.

In order to examine robustness of findings with regard to assumptions of normality, log-transformed outcomes were additionally examined, using the Stata LNSKEW0 routine. LNSKEW0 creates newvar= $\ln (+/-\exp -k)$, choosing $\mathrm{k}$ and the sign of exp so that the skewness of newvar is zero.

In order to assess to what degree associations between PRS and measures of psychosis proneness were independent, regression analyses were conducted for one measure of psychosis proneness, corrected for all the others. In order to examine to what degree any association between PRS and measures of psychosis proneness were mediated by IQ, IQ was added to the analyses as a covariate. 


\section{Results}

\section{Descriptive results and interaction by group}

Sample characteristics are displayed in Table 1. Values of the CAPE and SIS-R total score, lifetime depressive and manic episodes and PRS are shown in Table 2, by group and sex. CAPE and SIS-R subscale scores, by group and sex, are shown in Table 3.

The PRS of the healthy comparison subjects $(0.60$, S.D. $=0.21)$ was significantly lower than the PRS in the combined group of parents and siblings (0.83, S.D. $=$ $0.15 ; p<0.001)$. The PRS in the group of parents and siblings was significantly correlated with the PRS in the patient group $(r=0.30, p<0.0001)$.

Graphical examination of the scatterplots of PRS on the one hand and CAPE / SIS-R total scores (Fig. 1 $a-d$ ), CAPE subscale scores (Fig. 2a-f), SIS-R subscales scores (Fig. $3 a-d$ ) and IQ (Fig. $4 a, b$ ) on the other suggests association between PRS and various aspects of psychopathology and cognition in both groups.

\section{Associations in relatives and healthy comparison subjects}

Given the graphical suggestion of differences in the pattern of associations, analyses were conducted separately for relatives and the healthy comparison group. The pattern of correlation between the CAPE and SIS-R total and subscale scores were similar for relative and healthy comparison subjects, in that within-instrument scale correlations were high, whereas between-scale correlations were only moderate (Table 4).

Results of the multilevel random regression analyses are shown in Tables 5-7. In the relatives (Table 6), PRS was associated with CAPE total score $(B=0.12,95 \% \mathrm{CI}$ $0.02-0.22, p=0.015)$, SIS-R total score $(B=0.11,95 \% \mathrm{CI}$ $0.02-0.20, p=0.013)$ as well as with CAPE depression $(B=0.21,95 \%$ CI $0.07-0.34, p=0.004)$ and the SIS-R positive subscale $(B=0.16,95 \%$ CI $0.04-0.28, p=$ 0.008). Analyses with log-transformed scales showed similar results (Table 5). Analyses of the CAPE the SIS-R subscales, in which subscales were controlled for each other, showed that associations were reducible to the association with CAPE depression, which continued to be associated with PRS ( $B=0.10,95 \%$ CI $0.02-0.19, p=0.021)$ whereas the association with the SIS-R positive subscale was rendered non-significant (Table 5).

The association between CAPE depression and PRS was not affected by IQ, as the association with CAPE depression remained similar when IQ was added in addition to age and sex $(B=0.20,95 \%$ CI $0.06-0.34, p$ $=0.005$ ).

In the healthy comparison subjects (Table 6), PRS was associated with the SIS-R total score $(B=0.16$,
95\% CI $0.07-0.25, p=0.000)$ and both the SIS-R positive subscale $(B=0.22,95 \%$ CI $0.10-0.35, p=0.000)$ and the SIS-R negative subscale $(B=0.11,95 \%$ CI $0.03-0.19$, $p=0.10$ ) (Table 6). Analyses with log-transformed scales were similar (Table 6). In the analysis in which all subscales were controlled for each other, only the association with the SIS-R positive subscale remained significant $\quad(B=0.14, \quad 95 \% \quad C I \quad 0.05-0.24, \quad p=0.004$; Table 6).

Analyses of association between PRS and CASHbased lifetime depressive and manic episodes revealed evidence for association in both the relatives (OR any affective episode $=5.2,95 \%$ CI 1.6-16.7, $p=0.006)$ and the healthy comparison subjects (OR any affective episode $=4.0$, 95\% CI 1.2-13.1, $p=0.021$ ) (Table 7).

In the relatives, no large or significant association was apparent between PRS and IQ in a separate model of IQ, corrected for age and sex $(B=-1.8,95 \%$ CI -8.0 to $4.4 ; p=0.566)$. In the healthy comparison subjects, there was evidence for an association between IQ and PRS, adjusted for age and sex $(B=-8.5,95 \% \mathrm{CI}$ -15.5 to $-1.6 ; p=0.017$ ). The association between PRS and IQ in the healthy comparison subjects remained after controlling for SIS-R total score $(B=-7.5,95 \%$ CI -14.5 to $-0.4 ; p=0.038)$. Similarly, the association between PRS and SIS-R total score in the healthy comparison subjects remained after controlling for IQ $(B=$ $0.16,95 \%$ CI $0.07-0.25 ; p=0.001$ ).

\section{Sensitivity analyses at PRS p-threshold of 0.1}

Results for the sensitivity analyses were at the PRS p-threshold of 0.1 were very similar to the analyses at the P-threshold of 0.01 . The association between PRS and IQ was slightly weaker in the healthy comparison group $(B=-7.1,95 \% C I-15.1$ to $0.9, p=0.081)$. In the relatives group, associations between PRS and the CAPE positive and negative subscale were also significant and associations were not reducible to CAPE depression but to the SIS-R positive subscale.

\section{Discussion}

The main findings were that (i) PRS was pleiotropically associated with measures of affective dysregulation, aberrant salience and neurocognition; (ii) The association between neurocognition and PRS was present in the healthy comparison subjects but not in the relatives, and was independent of CAPE/SIS-R measures; (iii) Interview-based SIS-R measures appeared to be more sensitive than CAPE-based self-reports in detecting genetic association in the healthy comparison group.

According to the liability-threshold model, a person with a number of risk variants lower than or equal to 
Table 2. Depression and mania outcomes, and polygenic risk scores by group and by sex

\begin{tabular}{|c|c|c|c|c|c|c|c|}
\hline & \multicolumn{2}{|c|}{$\begin{array}{l}\text { \% Depressive } \\
\text { episode }^{\text {a }}\end{array}$} & \multicolumn{2}{|c|}{$\%$ Manic episode ${ }^{a}$} & \multicolumn{3}{|l|}{ PRS } \\
\hline & Rate & $N$ & Rate & $N$ & Mean & S.D. & $N$ \\
\hline \multicolumn{8}{|l|}{ Group } \\
\hline Healthy comparison subjects & 0.27 & 445 & 0.02 & 445 & 0.60 & 0.21 & 382 \\
\hline Sibs & 0.33 & 656 & 0.04 & 656 & 0.83 & 0.15 & 586 \\
\hline Parents & 0.30 & 583 & 0.02 & 583 & 0.83 & 0.15 & 610 \\
\hline \multicolumn{8}{|l|}{ Sex } \\
\hline Men & 0.22 & 739 & 0.03 & 739 & 0.77 & 0.20 & 720 \\
\hline Women & 0.37 & 945 & 0.03 & 945 & 0.77 & 0.19 & 858 \\
\hline Total & 0.30 & 1684 & 0.03 & 1684 & -0.28 & 0.55 & 1578 \\
\hline
\end{tabular}

PRS, polygenic risk score.

${ }^{\text {a }}$ Lifetime rate, calculated with baseline sample as denominator and including episodes occurring over the 6-year postbaseline follow-up period in the numerator.


Fig. 1. (a-d) Scatterplots with linear regression line of polygenic risk score (PRS) on the one hand, and, on the other, Community Assessment of Psychic Experiences (CAPE) total score in healthy comparison subjects (Fig. 1a) Structured Interview for Schizotypy - Revised (SIS-R) total score in healthy comparison subjects (Fig. 1b), CAPE total score in relatives (Fig. 1c) and SIS-R total score in relatives (Fig. 1d).

the critical threshold would not develop schizophrenia, whereas a person with more risk variants would (McGue et al. 1983). As individuals at higher than average genetic risk, such as the first-degree relatives of patients, have higher levels of psychometric and neurocognitive endophenotypes associated with psychotic disorder (Kendler et al. 1993; Toulopoulou et al. 2007), associations between PRS and such 
Table 3. Cape and SIS-R subscale scores by group and by sex

\begin{tabular}{|c|c|c|c|c|c|c|c|c|c|c|c|c|c|c|c|c|c|c|c|c|c|c|}
\hline \multirow{2}{*}{ Time } & & \multicolumn{2}{|c|}{ CAPE total } & & \multicolumn{2}{|c|}{ CAPE-POS } & & \multicolumn{2}{|c|}{ CAPE-NEG } & & \multicolumn{2}{|c|}{ CAPE-DEP } & & \multicolumn{2}{|c|}{ SIS-R total } & & \multicolumn{2}{|c|}{$\begin{array}{l}\text { SIS-R } \\
\text { positive }\end{array}$} & \multirow[b]{2}{*}{$n$} & \multicolumn{2}{|c|}{$\begin{array}{l}\text { SIS-R } \\
\text { negative }\end{array}$} & \\
\hline & & Mean & S.D. & & Mean & S.D. & & Mean & S.D. & & Mean & S.D. & & Mean & S.D. & & Mean & S.D. & & Mean & S.D. & \\
\hline & Group & & & & & & & & & & & & & & & & & & & & & \\
\hline \multirow[t]{3}{*}{1} & HCS & 0.42 & 0.23 & 502 & 0.19 & 0.17 & 500 & 0.48 & 0.32 & 500 & 0.59 & 0.34 & 502 & 0.27 & 0.25 & 515 & 0.30 & 0.35 & 515 & 0.24 & 0.23 & 514 \\
\hline & Siblings & 0.45 & 0.27 & 767 & 0.19 & 0.18 & 765 & 0.54 & 0.38 & 765 & 0.61 & 0.38 & 767 & 0.31 & 0.28 & 858 & 0.36 & 0.41 & 858 & 0.26 & 0.24 & 858 \\
\hline & Parents $^{\mathrm{a}}$ & 0.41 & 0.23 & 692 & 0.13 & 0.13 & 692 & 0.50 & 0.33 & 692 & 0.60 & 0.35 & 692 & 0.29 & 0.24 & 806 & 0.25 & 0.30 & 806 & 0.32 & 0.28 & 806 \\
\hline \multirow[t]{3}{*}{2} & HCS & 0.30 & 0.23 & 401 & 0.08 & 0.12 & 401 & 0.39 & 0.31 & 400 & 0.43 & 0.35 & 401 & 0.26 & 0.20 & 402 & 0.27 & 0.29 & 402 & 0.24 & 0.21 & 400 \\
\hline & Siblings & 0.35 & 0.28 & 675 & 0.10 & 0.14 & 673 & 0.46 & 0.40 & 674 & 0.49 & 0.40 & 675 & 0.29 & 0.25 & 683 & 0.31 & 0.34 & 683 & 0.28 & 0.25 & 683 \\
\hline & Parents ${ }^{\mathrm{a}}$ & - & - & - & - & - & - & - & - & - & - & - & - & - & - & - & - & - & - & - & - & - \\
\hline \multirow[t]{3}{*}{3} & HCS & 0.32 & 0.26 & 343 & 0.08 & 0.15 & 343 & 0.41 & 0.34 & 343 & 0.48 & 0.41 & 343 & 0.27 & 0.21 & 336 & 0.28 & 0.29 & 336 & 0.25 & 0.22 & 336 \\
\hline & Siblings & 0.35 & 0.28 & 594 & 0.08 & 0.12 & 593 & 0.47 & 0.40 & 593 & 0.50 & 0.41 & 594 & 0.30 & 0.24 & 598 & 0.31 & 0.31 & 598 & 0.29 & 0.25 & 598 \\
\hline & $\begin{array}{l}\text { Parents }{ }^{\mathrm{a}} \\
\text { Sex }\end{array}$ & - & - & - & - & - & - & - & - & - & - & - & - & - & - & - & - & - & - & - & - & - \\
\hline \multirow[t]{2}{*}{1} & Men & 0.40 & 0.23 & 890 & 0.17 & 0.16 & 889 & 0.50 & 0.33 & 889 & 0.52 & 0.32 & 890 & 0.28 & 0.25 & 984 & 0.28 & 0.33 & 984 & 0.29 & 0.27 & 983 \\
\hline & Women & 0.45 & 0.26 & 1071 & 0.17 & 0.17 & 1068 & 0.52 & 0.35 & 1068 & 0.67 & 0.38 & 1071 & 0.30 & 0.27 & 1195 & 0.33 & 0.38 & 1195 & 0.27 & 0.25 & 1195 \\
\hline \multirow[t]{2}{*}{2} & Men & 0.30 & 0.24 & 478 & 0.10 & 0.13 & 478 & 0.42 & 0.35 & 478 & 0.40 & 0.34 & 478 & 0.27 & 0.23 & 486 & 0.26 & 0.30 & 486 & 0.27 & 0.25 & 485 \\
\hline & Women & 0.36 & 0.28 & 598 & 0.09 & 0.13 & 596 & 0.45 & 0.39 & 596 & 0.53 & 0.40 & 598 & 0.29 & 0.24 & 599 & 0.32 & 0.34 & 599 & 0.26 & 0.23 & 598 \\
\hline \multirow[t]{2}{*}{3} & Men & 0.31 & 0.25 & 419 & 0.09 & 0.13 & 418 & 0.43 & 0.36 & 418 & 0.42 & 0.36 & 419 & 0.29 & 0.24 & 420 & 0.28 & 0.30 & 420 & 0.29 & 0.27 & 420 \\
\hline & Women & 0.36 & 0.29 & 518 & 0.08 & 0.13 & 518 & 0.46 & 0.39 & 518 & 0.55 & 0.44 & 518 & 0.29 & 0.22 & 514 & 0.31 & 0.31 & 514 & 0.27 & 0.22 & 514 \\
\hline
\end{tabular}

CAPE, Community Assessment of Psychic Experiences (subscales of positive, negative and depressive symptoms); SIS-R, Structured Interview for Schizotypy - Revised (subscales of positive and negative schizotypy).

${ }^{\text {a }}$ Parents baseline measures only. 

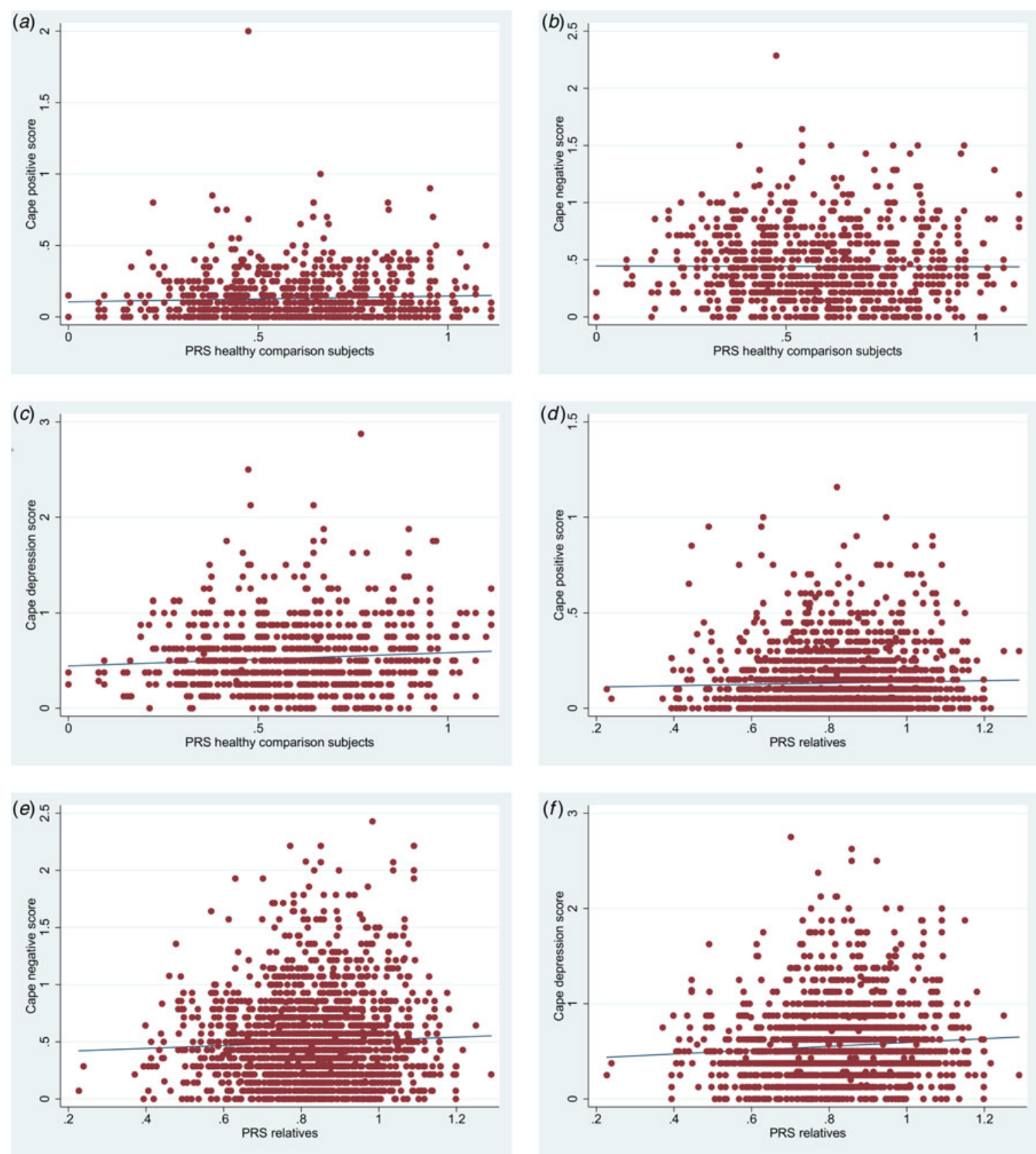

Fig. 2. (a-f) Scatterplots with linear regression line of polygenic risk score (PRS) on the one hand, and, on the other, Community Assessment of Psychic Experiences (CAPE) positive score in healthy comparison subjects (Fig. 2a), CAPE negative score in healthy comparison subjects (Fig. 2b), CAPE depression score in healthy comparison subjects (Fig. 2c), CAPE positive score in relatives (Fig. 2d), CAPE negative score in relatives (Fig. 2e), CAPE depression score in relatives (Fig. 2f).

endophenotypes may be more apparent in this group. However, in the current analysis, there was no evidence that associations between PRS and measures of psychopathology and cognition were stronger in the relatives of patients as compared with a group of healthy comparison subjects. Indeed, given stronger evidence for association between PRS and cognition in the healthy control group, the results suggest it may be more, not less difficult to demonstrate associations in the relatives.

A previous investigation in this sample, focussing on the association between childhood trauma and IQ reported a similar finding in that the association between IQ and childhood trauma was large in the healthy comparison group, intermediate in the relatives and not apparent in the patient group (Van Os 



Fig. 3. (a-d) Scatterplots with linear regression line of polygenic risk score (PRS) on the one hand, and, on the other, Structured Interview for Schizotypy - Revised (SIS-R) positive score in healthy comparison subjects (Fig. 3a), SIS-R negative score in healthy comparison subjects (Fig. 3b), SIS-R positive score in relatives (Fig. 3c), SIS-R negative score in relatives (Fig. 3d).
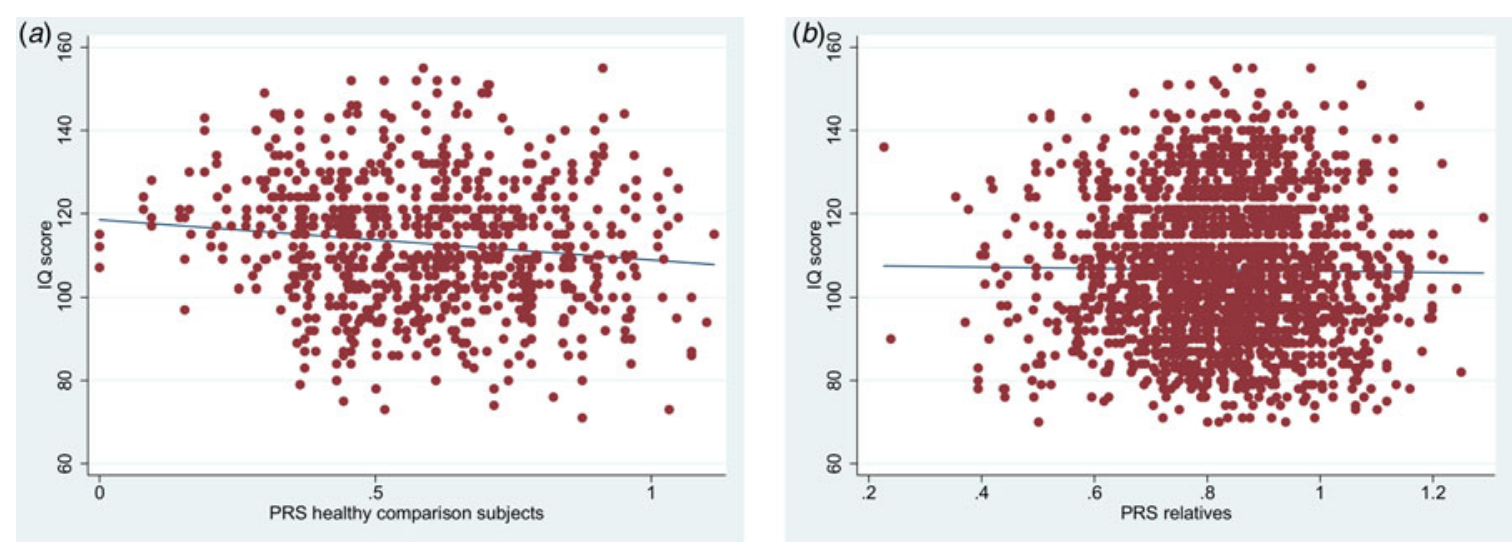

Fig. 4. $(a, b)$ Scatterplots with linear regression line of polygenic risk score (PRS) on the one hand and, on the other, intelligence quotient (IQ) score in the healthy comparison subjects (Fig. 4a) and IQ score in the relatives (Fig. 4b).

et al. 2017). Thus, in subjects at higher than average (environmental or genetic) risk, emerging expression of phenotypic alterations may create floor effects, obscuring associations. The results of this study again suggest that particularly measures in the neurodevelopmental domain may be sensitive to such a floor effect, as associations between PRS and subthreshold measures of psychopathology were apparent in both the relative and the healthy comparison groups. 
Table 4. Pattern of Pearson's correlation coefficients between psychopathology measures in relatives (top) and controls (bottom)

\begin{tabular}{|c|c|c|c|c|c|c|c|}
\hline Relatives & $\begin{array}{l}\text { SIS-R } \\
\text { total }\end{array}$ & $\begin{array}{l}\text { CAPE } \\
\text { total }\end{array}$ & $\begin{array}{l}\text { SIS-R } \\
\text { negative }\end{array}$ & $\begin{array}{l}\text { CAPE } \\
\text { negative }\end{array}$ & $\begin{array}{l}\text { SIS-R } \\
\text { positive }\end{array}$ & $\begin{array}{l}\text { CAPE } \\
\text { positive }\end{array}$ & $\begin{array}{l}\text { CAPE } \\
\text { depressive }\end{array}$ \\
\hline SIS-R total & 1 & & & & & & \\
\hline CAPE total & 0.50 & 1 & & & & & \\
\hline SIS-R negative & 0.82 & 0.42 & 1 & & & & \\
\hline CAPE negative & 0.45 & 0.92 & 0.43 & 1 & & & \\
\hline SIS-R positive & 0.88 & 0.42 & 0.44 & 0.35 & 1 & & \\
\hline CAPE positive & 0.38 & 0.65 & 0.19 & 0.48 & 0.42 & 1 & \\
\hline CAPE depressive & 0.45 & 0.93 & 0.39 & 0.75 & 0.38 & 0.49 & 1 \\
\hline \multicolumn{8}{|c|}{ Healthy comparison subjects } \\
\hline SIS-R total & 1 & & & & & & \\
\hline CAPE total & 0.46 & 1 & & & & & \\
\hline SIS-R negative & 0.82 & 0.36 & 1 & & & & \\
\hline CAPE negative & 0.40 & 0.90 & 0.36 & 1 & & & \\
\hline SIS-R positive & 0.89 & 0.42 & 0.46 & 0.33 & 1 & & \\
\hline CAPE positive & 0.33 & 0.68 & 0.16 & 0.49 & 0.39 & 1 & \\
\hline CAPE depressive & 0.43 & 0.92 & 0.35 & 0.72 & 0.38 & 0.50 & 1 \\
\hline
\end{tabular}

CAPE, Community Assessment of Psychic Experiences (subscales of positive, negative and depressive symptoms); SIS-R, Structured Interview for Schizotypy - Revised (subscales of positive and negative schizotypy).

Table 5. Results of regression analyses in relatives of patients (B, regression coefficient, $95 \% C I, 95 \%$ confidence interval; $p, p$ value; $n$, number of observations)

\begin{tabular}{|c|c|c|c|c|c|c|c|c|c|}
\hline & \multicolumn{3}{|c|}{$\begin{array}{l}\text { Association of psychopathology } \\
\text { measure with PRS }\end{array}$} & \multicolumn{3}{|c|}{$\begin{array}{l}\text { Association of log-transformed } \\
\text { psychopathology measure with } \\
\text { PRS }\end{array}$} & \multicolumn{3}{|c|}{$\begin{array}{l}\text { Association of psychopathology } \\
\text { subscales with PRS, corrected for } \\
\text { the other subscales }\end{array}$} \\
\hline & B $(95 \% \mathrm{CI})$ & $p$ & $n$ & $\mathrm{~B}(95 \% \mathrm{CI})$ & $p$ & $n$ & B $(95 \%$ CI $)$ & $p$ & $n$ \\
\hline \multicolumn{10}{|l|}{ Measure } \\
\hline CAPE total & $0.12(0.02-0.22)$ & 0.015 & 1916 & $0.16(0.01-0.31)$ & 0.032 & 1916 & $\mathrm{NA}^{\mathrm{a}}$ & & \\
\hline CAPE positive & $0.04(-0.02$ to 0.10$)$ & 0.150 & 1913 & $0.32(-0.01$ to 0.65$)$ & 0.059 & 1913 & $-0.01(-0.05$ to 0.04$)$ & 0.830 & 1884 \\
\hline CAPE negative & $0.13(-0.01$ to 0.27$)$ & 0.075 & 1914 & $0.12(-0.05$ to 0.28$)$ & 0.170 & 1914 & $-0.04(-0.13$ to 0.05$)$ & 0.385 & 1884 \\
\hline CAPE depressive & $0.21(0.07-0.34)$ & 0.004 & 1916 & $0.21(0.07-0.36)$ & 0.005 & 1916 & $0.10(0.02-0.19)$ & 0.021 & 1884 \\
\hline SIS-R total & $0.11(0.02-0.20)$ & 0.013 & 2071 & $0.24(0.04-0.43)$ & 0.016 & 2071 & $\mathrm{NA}^{\mathrm{a}}$ & & \\
\hline SIS-R positive & $0.16(0.04-0.28)$ & 0.008 & 2071 & $0.51(0.19-0.83)$ & 0.002 & 2071 & $0.08(-0.02$ to 0.18$)$ & 0.136 & 1884 \\
\hline SIS-R negative & $0.08(-0.02$ to 0.17$)$ & 0.103 & 2071 & $0.14(-0.06$ to 0.33$)$ & 0.166 & 2071 & $0.02(-0.06$ to 0.10$)$ & 0.616 & 1884 \\
\hline
\end{tabular}

${ }^{a}$ NA: analyses were conducted with the five subscales: CAPE positive, CAPE negative, CAPE depressive, SIS-R positive, SIS-R negative.

PRS, polygenic risk score; CAPE, Community Assessment of Psychic Experiences (subscales of positive, negative and depressive symptoms); SIS-R, Structured Interview for Schizotypy - Revised (subscales of positive and negative schizotypy).

\section{Affective dysregulation, aberrant salience and genetic liability to psychosis}

There is a well-established link between affective dysregulation and psychosis, both at the level of clinical illness (Tsuang \& Dempsey, 1979; McMillan et al.
2009), subthreshold psychotic experiences (Verdoux et al. 1999; Hanssen et al. 2003; Van Rossum et al. 2011; Varghese et al. 2011; Wigman et al. 2012; Stochl et al. 2015), so-called clinical high-risk states (Fusar-Poli et al. 2014) and in the early prodromal 
Table 6. Results of regression analyses in healthy comparison subjects ( $B$, regression coefficient, $95 \%$ CI, 95\% confidence interval; $p$, $p$ value; $n$, number of observations)

\begin{tabular}{|c|c|c|c|c|c|c|c|c|c|}
\hline & \multicolumn{3}{|c|}{$\begin{array}{l}\text { Association of psychopathology } \\
\text { measure with PRS\# }\end{array}$} & \multicolumn{3}{|c|}{$\begin{array}{l}\text { Association of log-transformed } \\
\text { psychopathology measure with } \\
\text { PRS\# }\end{array}$} & \multicolumn{3}{|c|}{$\begin{array}{l}\text { Association of psychopathology } \\
\text { subscales with PRS\#, corrected for } \\
\text { the other subscales }\end{array}$} \\
\hline & B $(95 \%$ CI $)$ & $p$ & $n$ & B $(95 \%$ CI $)$ & $p$ & $n$ & B $(95 \%$ CI $)$ & $p$ & $n$ \\
\hline \multicolumn{10}{|l|}{ Measure } \\
\hline CAPE total & $0.04(-0.07$ to 0.14$)$ & 0.465 & 911 & $0.01(-0.17$ to 0.19$)$ & 0.917 & 911 & $\mathrm{NA}^{\mathrm{a}}$ & & \\
\hline CAPE positive & $0.03(-0.04$ to 0.10$)$ & 0.451 & 910 & $0.20(-0.27$ to 0.66$)$ & 0.400 & 910 & $-0.00(-0.06$ to 0.05$)$ & 0.872 & 889 \\
\hline CAPE negative & $-0.01(-0.15$ to 0.12$)$ & 0.848 & 909 & $-0.07(-0.24$ to 0.10$)$ & 0.431 & 909 & $-0.10(-0.19$ to 0.01$)$ & 0.030 & 889 \\
\hline CAPE depressive & $0.11(-0.04$ to 0.26$)$ & 0.157 & 911 & $0.07(-0.11$ to 0.24$)$ & 0.441 & 911 & $0.08(-0.01$ to 0.18$)$ & 0.093 & 889 \\
\hline SIS-R total & $0.16(0.07-0.25)$ & 0.000 & 921 & $0.40(0.18-0.63)$ & 0.000 & 921 & $\mathrm{NA}^{\mathrm{a}}$ & & \\
\hline SIS-R positive & $0.22(0.10-0.35)$ & 0.000 & 921 & $0.60(0.28-0.93)$ & 0.000 & 921 & $0.14(0.05-0.24)$ & 0.004 & 889 \\
\hline SIS-R negative & $0.11(0.03-0.19)$ & 0.010 & 919 & $0.31(0.09-0.52)$ & 0.005 & 919 & $0.04(-0.03$ to 0.11$)$ & 0.244 & 889 \\
\hline
\end{tabular}

${ }^{a}$ NA: analyses were conducted with the five subscales: CAPE positive, CAPE negative, CAPE depressive, SIS-R positive, SIS-R negative.

\#PRS, polygenic risk score; CAPE, Community Assessment of Psychic Experiences (subscales of positive, negative and depressive symptoms); SIS-R = Structured Interview for Schizotypy - Revised (subscales of positive and negative schizotypy).

Table 7. Results of regression analyses in baseline sample for lifetime manic and depressive episodes (including episodes over 6-year follow-up) in relatives and healthy comparison subjects. Odds ratio reflects association between polygenic risk score on the one hand, and depressive/manic episode on the other (OR, odds ratio; 95\% CI, 95\% confidence interval; $p$, $p$ value; $n$, number of observations)

\begin{tabular}{|c|c|c|c|c|c|c|}
\hline & \multicolumn{3}{|l|}{ Relatives } & \multicolumn{3}{|c|}{ Healthy comparison subjects } \\
\hline & OR $(95 \% \mathrm{CI})$ & $p$ & $n$ & OR $(95 \% \mathrm{CI})$ & $p$ & $n$ \\
\hline \multicolumn{7}{|l|}{ Measure } \\
\hline Depressive episode & $2.6(0.9-7.9)$ & 0.089 & 869 & $3.4(0.9-13.0)$ & 0.069 & 323 \\
\hline Manic episode & $6.4(0.3-132.6)$ & 0.228 & 869 & $0.7(0.01-38.2)$ & 0.867 & 323 \\
\hline Affective episode ${ }^{a}$ & $3.1(1.04-9.3)$ & 0.043 & 869 & $3.4(0.9-12.7)$ & 0.075 & 323 \\
\hline
\end{tabular}

${ }^{a}$ Any depressive or manic episode.

stages (Hafner et al. 1999). In addition, many studies have suggested an important role of affective dysregulation in the formation of psychotic symptoms (Freeman \& Garety, 1999; Garety et al. 2001; Freeman \& Garety, 2003; Myin-Germeys \& van Os, 2007; Fowler et al. 2012), and molecular genetic studies suggest an overlap between schizophrenia and affective illness (Cross-Disorder Group of the Psychiatric Genomics and Genetic Risk Outcome of Psychosis, 2013; Cross-Disorder Group of the Psychiatric Genomics et al. 2013).

There is evidence that psychosis represents a severity dimension of an initial state of affective dysregulation (Kelleher et al. 2012; Wigman et al. 2012) and that clinical high risk samples with high risk of conversion to psychotic disorder mainly consist of individuals with affective dysregulation (Addington et al. 2007). Therefore, early states of affective dysregulation may give rise to more severe states in which psychotic symptoms arise (Van Os \& Reininghaus, 2016). Additional exposure may be required for psychotic symptom formation, research showing higher risks of psychotic symptom formation with progressively greater level of exposure to environmental risk factors (Cougnard et al. 2007; Guloksuz et al. 2015; Van Nierop et al. 2015).

The findings agree with the literature, suggesting that the association between genetic risk and psychosis proneness is not only mediated by psychoticism and neurodevelopmental alterations, but also by measures 
of affective dysregulation. The effects of polygenic risk thus may be examined further in network models, focussing particularly on the strength of the connection between affective dysregulation, cognition and psychotic symptoms. Similarly, gene-environment interactions may converge at the level of the connection between affective dysregulation, cognition and psychotic symptoms.

\section{Cognitive alterations and neurodevelopmental hypothesis}

The premorbid cognitive alterations in schizophrenia are one of the core findings supporting the neurodevelopmental hypothesis (Jones et al. 1994). There was evidence for an association between IQ and PRS, however it may be hypothesized that environmental exposures such as childhood trauma, that have been shown to also impact cognitive development (Majer et al. 2010; Gould et al. 2012; Maguire et al. 2015; Philip et al. 2016) may also play a causal role in the development of cognitive alterations in psychosis (Lysaker et al. 2001; Aas et al. 2012; Sahu et al. 2016; Van Os et al. 2017). In addition, genetic variation and epistasis not included in the PRS may contribute to cognitive alterations as well. It has been reported that less than a fifth of the effect of family history on the occurrence of psychotic disorder is mediated by PRS (Agerbo et al. 2015), leaving room for the impact of other genetic factors, assuming not all of the remainder of the effect of family history is 'environmental'.

Given evidence that most of the overall effect of a schizophrenia diagnosis on cognitive performance is mediated through a single common factor, indicating that a generalized cognitive deficit is a core underlying feature (Dickinson et al. 2004), a general measure like IQ arguably is the most useful to examine in the context of associations with PRS. There have been conflicting reports on associations between measures of cognition and schizophrenia polygenic scores in patient and control samples using a variety of different cognitive measures (Hatzimanolis et al. 2015; Hubbard et al. 2016; Mark \& Toulopoulou, 2016), however no previous report has examined the association in a large sample of non-ill individuals at higher than average genetic risk with repeated measures of IQ over time. Given evidence for an association between PRS and IQ in healthy control group, it may be hypothesized that PRS for schizophrenia is expressed, at least in part, as a cognitive measure that correlates with IQ.

\section{Methodological issues}

The results should be interpreted in the light of several methodological considerations. First, although the sample size was substantial, it was still relatively small for a molecular genetic study. Nevertheless, effect sizes were detectable. A previous general population study with a larger sample suggested a weak association with CAPE negative scores however in that study (Jones et al. 2016), CAPE positive and CAPE depression scores were not included. Given that CAPE negative scores are strongly associated with CAPE depression scores (0.7 in the current study), the reported association with CAPE negative scores may be considered compatible with the current findings (van Os, 2016), given that CAPE depression in the healthy comparison group directionally showed the same type of association as in the relatives, albeit weaker. In any case, the results of this study show that self-reports of psychosis-proneness in the general population may not be sensitive in detecting genetic associations. Second, it could be argued that lack of association between IQ and PRS in the relatives cannot be interpreted fully without examination of the association between IQ and PRS in their patient relatives; if the association is present in the patient group but not in their relatives, this may indicate that PRS can contribute to IQ in interaction with other genetic or non-genetic factors that patients may have been differentially exposed to. However, analysis of the association between repeated measure of IQ and PRS in the patient group (1304 observations in 596 patients) similarly yielded no evidence of association $(B=1.7$, $95 \% \mathrm{CI}-4.5$ to $7.9 ; p=0.597)$. Third, it could be argued that the association between PRS and measures of affective dysregulation in the relatives is confounded by PRS-associated poor illness outcome in the patients, negatively impacting mental health of the relatives. However, the absence of an association between PRS and cognitive alterations, which are associated with poor outcome, makes it unlikely that PRS is associated with poor outcome. Although PRS was associated with positive symptoms of psychosis, positive symptoms are not associated with poor outcome. In order to verify this issue analytically, we re-examined the association between PRS and CAPE depression, additionally adjusting the analysis for the following outcome measures in the patient relative: number of unmet needs, measures with the Camberwell Assessment of Needs (Slade et al. 1996), GAF-symptoms and GAF-disability (World Health Organisation, 1992). This adjustment did not reduce the association $(B=$ $0.22,95 \%$ CI $0.08-0.36, p=0.003)$. Finally, although two different genotyping platforms were used, one for controls and another for relatives, the use of imputation across platforms can be considered an effective way to control for this. In addition, analyses in the relatives were entirely within-platform, and analyses in the healthy comparison subjects was also largely within platform. 


\section{Acknowledgements}

The infrastructure for the GROUP study is funded through the Geestkracht programme of the Dutch Health Research Council (ZON-MW, grant number 10-000-1001), and matching funds from participating industry (Lundbeck, AstraZeneca, Eli Lilly, Janssen Cilag), universities and mental health care organizations (Amsterdam: Academic Psychiatric Centre of the Academic Medical Center and the mental health institutions: GGZ Ingeest, Arkin, Dijk en Duin, GGZ Rivierduinen, Erasmus Medical Centre, GGZ Noord Holland Noord. Maastricht: Maastricht University Medical Centre and the mental health institutions: GGZ Eindhoven en De Kempen, GGZ Breburg, GGZ Oost-Brabant, Vincent van Gogh voor Geestelijke Gezondheid, Mondriaan, Zuyderland, MetGGZ, Riagg-Virenze Maastricht, Universitair Centrum Sint-Jozef Kortenberg, CAPRI University of Antwerp, PC Ziekeren Sint-Truiden, PZ Sancta Maria Sint-Truiden, GGZ Overpelt, OPZ Rekem. Groningen: University Medical Center Groningen and the mental health institutions: Lentis, GGZ Friesland, GGZ Drenthe, Dimence, Mediant, GGNet Warnsveld, Yulius Dordrecht and Parnassia psycho-medical center The Hague. Utrecht: University Medical Center Utrecht and the mental health institutions Altrecht, GGZ Centraal, Riagg Amersfoort and Delta). Funded in part by the European Community's Seventh Framework Program under grant agreement No. HEALTH-F2-2009-241909 (Project EU-GEI). We are grateful for the generosity, in terms of time and effort, shown by the patients, their families and the healthy comparison subjects and for the continuing collaboration with all the researchers who made the GROUP project possible. Furthermore, we would like to thank all research personnel involved in the GROUP project, in particular: Joyce van Baaren, Erwin Veermans, Ger Driessen, Truda Driesen, Karin Pos, Erna van 't Hag, Jessica de Nijs, Wendy Beuken and Debora Op 't Eijnde.

\section{References}

Aas M, Steen NE, Agartz I, Aminoff SR, Lorentzen S, Sundet K, Andreassen OA, Melle I (2012). Is cognitive impairment following early life stress in severe mental disorders based on specific or general cognitive functioning? Psychiatry Research 198, 495-500.

Addington D, Addington J, Maticka-Tyndale E (1993). Assessing depression in schizophrenia: the Calgary Depression Scale. British Journal of Psychiatry Supplement 22, 39-44.

Addington J, Cadenhead KS, Cannon TD, Cornblatt B, Mcglashan TH, Perkins DO, Seidman LJ, Tsuang M, Walker EF, Woods SW, Heinssen R (2007). North American Prodrome Longitudinal Study: a collaborative multisite approach to prodromal schizophrenia research. Schizophrenia Bulletin 33, 665-672.

Agerbo E, Sullivan PF, Vilhjalmsson BJ, Pedersen CB, Mors O, Borglum AD, Hougaard DM, Hollegaard MV, Meier S, Mattheisen M, Ripke S, Wray NR, Mortensen PB (2015). Polygenic risk score, parental socioeconomic status, family history of psychiatric disorders, and the risk for schizophrenia: a Danish population-based study and Meta-analysis. JAMA Psychiatry 72, 635-641.

American Psychiatric Association (2000). Diagnostic and Statistical Manual of Mental Disorders, 4th edn. Text Revision. American Psychiatric Association: Washington, DC.

Andreasen NC (1982). Negative symptoms in schizophrenia. Definition and reliability. Archives of General Psychiatry 39, 784-788.

Andreasen NC, Flaum M, Arndt S (1992). The Comprehensive Assessment of Symptoms and History (CASH). An instrument for assessing diagnosis and psychopathology. Archives of General Psychiatry 49, 615-623.

Blyler CR, Gold JM, Iannone VN, Buchanan RW (2000). Short form of the WAIS-III for use with patients with schizophrenia. Schizophrenia Research 46, 209-215.

Cardno AG, Marshall EJ, Coid B, Macdonald AM, Ribchester TR, Davies NJ, Venturi P, Jones LA, Lewis SW, Sham PC, Gottesman Ii, Farmer AE, Mcguffin P, Reveley AM, Murray RM (1999). Heritability estimates for psychotic disorders: the Maudsley twin psychosis series. Archives of General Psychiatry 56, 162-168.

Cougnard A, Marcelis M, Myin-Germeys I, De Graaf R, Vollebergh W, Krabbendam L, Lieb R, Wittchen HU, Henquet C, Spauwen J, Van Os J (2007). Does normal developmental expression of psychosis combine with environmental risk to cause persistence of psychosis? A psychosis proneness-persistence model. Psychological Medicine 37, 513-527.

Cross-Disorder Group of the Psychiatric Genomics C, Genetic Risk Outcome of Psychosis C (2013).

Identification of risk loci with shared effects on five major psychiatric disorders: a genome-wide analysis. Lancet 381, 1371-1379.

Cross-Disorder Group of the Psychiatric Genomics C, Lee SH, Ripke S, Neale BM, Faraone SV, Purcell SM, Perlis RH, Mowry BJ, Thapar A, Goddard ME, Witte JS, Absher D, Agartz I, Akil H, Amin F, Andreassen OA, Anjorin A, Anney R, Anttila V, Arking DE, Asherson P, Azevedo MH, Backlund L, Badner JA, Bailey AJ, Banaschewski T, Barchas JD, Barnes MR, Barrett TB, Bass N, Battaglia A, Bauer M, Bayes M, Bellivier F, Bergen SE, Berrettini W, Betancur C, Bettecken T, Biederman J, Binder EB, Black DW, Blackwood DH, Bloss CS, Boehnke M, Boomsma DI, Breen G, Breuer R, Bruggeman R, Cormican P, Buccola NG, Buitelaar JK, Bunney WE, Buxbaum JD, Byerley WF, Byrne EM, Caesar S, Cahn W, Cantor RM, Casas M, Chakravarti A, Chambert K, Choudhury K, Cichon S, Cloninger CR, Collier DA, Cook EH, Coon H, Cormand B, Corvin A, Coryell WH, Craig DW, Craig IW, Crosbie J, Cuccaro ML, Curtis D, Czamara D, Datta S, Dawson G, Day R, De Geus EJ, Degenhardt F, Djurovic S, Donohoe GJ, Doyle AE, Duan J, Dudbridge F, 
Duketis E, Ebstein RP, Edenberg HJ, Elia J, Ennis S, Etain B, Fanous A, Farmer AE, Ferrier IN, Flickinger M, Fombonne E, Foroud T, Frank J, Franke B, Fraser C, Freedman R, Freimer NB, Freitag CM, Friedl M, Frisen L, Gallagher $L$, Gejman PV, Georgieva L, Gershon ES, Geschwind DH, Giegling I, Gill M, Gordon SD, Gordon-Smith K, Green EK, Greenwood TA, Grice DE, Gross M, Grozeva D, Guan W, Gurling H, De Haan L, Haines JL, Hakonarson H, Hallmayer J, Hamilton SP, Hamshere ML, Hansen TF, Hartmann AM, Hautzinger M, Heath AC, Henders AK, Herms S, Hickie IB, Hipolito M, Hoefels S, Holmans PA, Holsboer F, Hoogendijk WJ, Hottenga JJ, Hultman CM, Hus V, Ingason A, Ising M, Jamain S, Jones EG, Jones I, Jones L, Tzeng JY, Kahler AK, Kahn RS, Kandaswamy R, Keller MC, Kennedy JL, Kenny E, Kent L, Kim Y, Kirov GK, Klauck SM, Klei L, Knowles JA, Kohli MA, Koller DL, Konte B, Korszun A, Krabbendam L, Krasucki R, Kuntsi J, Kwan $\mathrm{P}$, Landen $\mathrm{M}$, Langstrom N, Lathrop $\mathrm{M}$, Lawrence J, Lawson WB, Leboyer $M$, Ledbetter DH, Lee PH, Lencz $T$, Lesch KP, Levinson DF, Lewis CM, Li J, Lichtenstein P, Lieberman JA, Lin DY, Linszen DH, Liu C, Lohoff FW, Loo SK, Lord C, Lowe JK, Lucae S, Macintyre DJ, Madden PA, Maestrini E, Magnusson PK, Mahon PB, Maier W, Malhotra AK, Mane SM, Martin CL, Martin NG, Mattheisen M, Matthews K, Mattingsdal M, Mccarroll SA, Mcghee KA, Mcgough JJ, Mcgrath PJ, Mcguffin P, Mcinnis MG, Mcintosh A, Mckinney R, Mclean AW, Mcmahon FJ, Mcmahon WM, Mcquillin A, Medeiros H, Medland SE, Meier S, Melle I, Meng F, Meyer J, Middeldorp CM, Middleton L, Milanova V, Miranda A, Monaco AP, Montgomery GW, Moran JL, Moreno-De-Luca D, Morken G, Morris DW, Morrow EM, Moskvina V, Muglia P, Muhleisen TW, Muir WJ, Muller-Myhsok B, Murtha M, Myers RM, Myin-Germeys I, Neale MC, Nelson SF, Nievergelt CM, Nikolov I, Nimgaonkar V, Nolen WA, Nothen MM, Nurnberger JI, Nwulia EA, Nyholt DR, O'dushlaine C, Oades RD, Olincy A, Oliveira G, Olsen L, Ophoff RA, Osby U, Owen MJ, Palotie A, Parr JR, Paterson AD, Pato CN, Pato MT, Penninx BW, Pergadia ML, Pericak-Vance MA, Pickard BS, Pimm J, Piven J, Posthuma D, Potash JB, Poustka F, Propping P, Puri V, Quested DJ, Quinn EM, Ramos-Quiroga JA, Rasmussen HB, Raychaudhuri S, Rehnstrom K, Reif A, Ribases M, Rice JP, Rietschel M, Roeder K, Roeyers H, Rossin L, Rothenberger A, Rouleau G, Ruderfer D, Rujescu D, Sanders AR, Sanders SJ, Santangelo SL, Sergeant JA, Schachar R, Schalling M, Schatzberg AF, Scheftner WA, Schellenberg GD, Scherer SW, Schork NJ, Schulze TG, Schumacher J, Schwarz M, Scolnick E, Scott LJ, Shi J, Shilling PD, Shyn SI, Silverman JM, Slager SL, Smalley SL, Smit JH, Smith EN, Sonuga-Barke EJ, St Clair D, State M, Steffens M, Steinhausen HC, Strauss JS, Strohmaier J, Stroup TS, Sutcliffe JS, Szatmari $P$, Szelinger $S$, Thirumalai $S$, Thompson RC, Todorov AA, Tozzi F, Treutlein J, Uhr M, Van Den Oord EJ, Van Grootheest G, Van Os J, Vicente AM, Vieland VJ, Vincent JB, Visscher PM, Walsh CA, Wassink TH, Watson SJ, Weissman MM, Werge T, Wienker TF, Wijsman EM, Willemsen G, Williams N, Willsey AJ, Witt SH, Xu W, Young AH, Yu TW, Zammit S, Zandi PP,
Zhang P, Zitman FG, Zollner S, Devlin B, Kelsoe JR, Sklar P, Daly MJ, O'donovan MC, Craddock N, Sullivan PF, Smoller JW, Kendler KS, Wray NR, International Inflammatory Bowel Disease Consortium CuminsCoGenetics C (2013). Genetic relationship between five psychiatric disorders estimated from genome-wide SNPs. Nature Genetics 45, 984-994.

Dickinson D, Iannone VN, Wilk CM, Gold JM (2004). General and specific cognitive deficits in schizophrenia. Biological Psychiatry 55, 826-833.

Euesden J, Lewis CM, O'reilly PF (2015). PRSice: Polygenic Risk Score software. Bioinformatics 31, 1466-1468.

Fowler D, Hodgekins J, Garety P, Freeman D, Kuipers E, Dunn G, Smith B, Bebbington PE (2012). Negative cognition, depressed mood, and paranoia: a longitudinal pathway analysis using structural equation modeling. Schizophrenia Bulletin 38, 1063-1073.

Freeman D, Garety PA (1999). Worry, worry processes and dimensions of delusions: an exploratory investigation of a role for anxiety processes in the maintenance of delusional distress. Behavioural and Cognitive Psychotherapy 27, 47-62.

Freeman D, Garety PA (2003). Connecting neurosis and psychosis: the direct influence of emotion on delusions and hallucinations. Behaviour Research and Therapy 41, 923-947.

Fusar-Poli P, Nelson B, Valmaggia L, Yung AR, Mcguire PK (2014). Comorbid depressive and anxiety disorders in 509 individuals with an at-risk mental state: impact on psychopathology and transition to psychosis. Schizophrenia Bulletin 40, 120-131.

Garety PA, Kuipers E, Fowler D, Freeman D, Bebbington PE (2001). A cognitive model of the positive symptoms of psychosis. Psychological Medicine 31, 189-195.

Gould F, Clarke J, Heim C, Harvey PD, Majer M, Nemeroff CB (2012). The effects of child abuse and neglect on cognitive functioning in adulthood. Journal of Psychiatric Research 46, 500-506.

Guloksuz S, Van Nierop M, Lieb R, Van Winkel R, Wittchen HU, Van Os J (2015). Evidence that the presence of psychosis in non-psychotic disorder is environment-dependent and mediated by severity of non-psychotic psychopathology. Psychological Medicine 45, 2389-2401.

Hafner H, Loffler W, Maurer K, Hambrecht M, An Der Heiden W (1999). Depression, negative symptoms, social stagnation and social decline in the early course of schizophrenia. Acta Psychiatrica Scandinavica. Aug 100, 105-118.

Hanssen M, Peeters F, Krabbendam L, Radstake S, Verdoux H, Van Os J (2003). How psychotic are individuals with non-psychotic disorders? Social Psychiatry and Psychiatric Epidemiology 38, 149-154.

Hatzimanolis A, Bhatnagar P, Moes A, Wang R, Roussos P, Bitsios P, Stefanis CN, Pulver AE, Arking DE, Smyrnis N, Stefanis NC, Avramopoulos D (2015). Common genetic variation and schizophrenia polygenic risk influence neurocognitive performance in young adulthood. American Journal of Medical Genetics B Neuropsychiatric Genetics 168b, 392-401.

Hubbard L, Tansey KE, Rai D, Jones P, Ripke S, Chambert KD, Moran JL, Mccarroll SA, Linden DE, Owen MJ, O'donovan MC, Walters JT, Zammit S (2016). Evidence of 
common genetic overlap between Schizophrenia and cognition. Schizophrenia Bulletin 42, 832-842.

Iyegbe C, Campbell D, Butler A, Ajnakina O, Sham P (2014). The emerging molecular architecture of schizophrenia, polygenic risk scores and the clinical implications for GxE research. Social Psychiatry and Psychiatric Epidemiology 49, 169-182.

Jeppesen P, Larsen JT, Clemmensen L, Munkholm A, Rimvall MK, Rask CU, Van Os J, Petersen L, Skovgaard AM (2015). The CCC2000 birth Cohort Study of register-based family history of mental disorders and psychotic experiences in offspring. Schizophrenia Bulletin 41, 1084-1094.

Jones HJ, Stergiakouli E, Tansey KE, Hubbard L, Heron J, Cannon M, Holmans $P$, Lewis G, Linden DE, Jones PB, Davey Smith G, O'donovan MC, Owen MJ, Walters JT, Zammit S (2016). Phenotypic manifestation of genetic risk for schizophrenia during adolescence in the general population. JAMA Psychiatry 73, 221-228.

Jones P, Rodgers B, Murray R, Marmot M (1994). Child development risk factors for adult schizophrenia in the British 1946 birth cohort. Lancet 344, 1398-1402.

Kelleher I, Keeley H, Corcoran P, Lynch F, Fitzpatrick C, Devlin N, Molloy C, Roddy S, Clarke MC, Harley M, Arseneault L, Wasserman C, Carli V, Sarchiapone M, Hoven C, Wasserman D, Cannon M (2012).

Clinicopathological significance of psychotic experiences in non-psychotic young people: evidence from four population-based studies. British Journal of Psychiatry 201, 26-32.

Kendler KS, Lieberman JA, Walsh D (1989). The structured interview for Schizotypy (SIS): a preliminary report. Schizophrenia Bulletin 15, 559-571.

Kendler KS, Mcguire M, Gruenberg AM, O'hare A, Spellman M, Walsh D (1993). The Roscommon Family Study. III. Schizophrenia-related personality disorders in relatives. Archives of General Psychiatry 50, 781-788.

Konings M, Bak M, Hanssen M, Van Os J, Krabbendam L (2006). Validity and reliability of the CAPE: a self-report instrument for the measurement of psychotic experiences in the general population. Acta Psychiatrica Scandinavica 114, 55-61.

Korver N, Quee PJ, Boos HB, Simons CJ, De Haan L, Group Investigators (2012). Genetic Risk and Outcome of Psychosis (GROUP), a multi-site longitudinal cohort study focused on gene-environment interaction: objectives, sample characteristics, recruitment and assessment methods. International Journal of Methods in Psychiatric Research 21, 205-221.

Linscott RJ, Van Os J (2013). An updated and conservative systematic review and meta-analysis of epidemiological evidence on psychotic experiences in children and adults: on the pathway from proneness to persistence to dimensional expression across mental disorders. Psychological Medicine 43, 1133-1149.

Lysaker PH, Meyer PS, Evans JD, Clements CA, Marks KA (2001). Childhood sexual trauma and psychosocial functioning in adults with schizophrenia. Psychiatric Services 52, 1485-1488.

Maguire SA, Williams B, Naughton AM, Cowley LE, Tempest V, Mann MK, Teague M, Kemp AM (2015). A systematic review of the emotional, behavioural and cognitive features exhibited by school-aged children experiencing neglect or emotional abuse. Child: Care, Health and Development 41, 641-653.

Majer M, Nater UM, Lin JM, Capuron L, Reeves WC (2010). Association of childhood trauma with cognitive function in healthy adults: a pilot study. BMC Neurology 10, 61 .

Marden JR, Walter S, Tchetgen Tchetgen EJ, Kawachi I, Glymour MM (2014). Validation of a polygenic risk score for dementia in black and white individuals. Brain and Behavior 4, 687-697.

Mark W, Toulopoulou T (2016). Cognitive intermediate phenotype and genetic risk for psychosis. Current Opinion in Neurobiology 36, 23-30.

Mccarthy S, Das S, Kretzschmar W, Delaneau O, Wood AR, Teumer A, Kang HM, Fuchsberger C, Danecek P, Sharp K, Luo Y, Sidore C, Kwong A, Timpson N, Koskinen S, Vrieze S, Scott LJ, Zhang H, Mahajan A, Veldink J, Peters U, Pato C, Van Duijn CM, Gillies CE, Gandin I, Mezzavilla M, Gilly A, Cocca M, Traglia M, Angius A, Barrett JC, Boomsma D, Branham K, Breen G, Brummett CM, Busonero F, Campbell H, Chan A, Chen S, Chew E, Collins FS, Corbin LJ, Smith GD, Dedoussis G, Dorr M, Farmaki AE, Ferrucci L, Forer L, Fraser RM, Gabriel S, Levy S, Groop L, Harrison T, Hattersley A, Holmen OL, Hveem K, Kretzler M, Lee JC, Mcgue M, Meitinger T, Melzer D, Min JL, Mohlke KL, Vincent JB, Nauck M, Nickerson D, Palotie A, Pato M, Pirastu N, Mcinnis M, Richards JB, Sala C, Salomaa V, Schlessinger D, Schoenherr S, Slagboom PE, Small K, Spector T, Stambolian D, Tuke M, Tuomilehto J, Van Den Berg LH, Van Rheenen W, Volker U, Wijmenga C, Toniolo D, Zeggini E, Gasparini P, Sampson MG, Wilson JF, Frayling T, De Bakker PI, Swertz MA, Mccarroll S, Kooperberg C, Dekker A, Altshuler D, Willer C, Iacono W, Ripatti S, Soranzo N, Walter K, Swaroop A, Cucca F, Anderson CA, Myers RM, Boehnke M, Mccarthy MI, Durbin R, Haplotype Reference Consortium (2016). A reference panel of 64976


1279-1283.

Mcgue M, Gottesman Ii, Rao DC (1983). The transmission of schizophrenia under a multifactorial threshold model. American Journal of Human Genetics 35, 1161-1178.

Mcmillan KA, Enns MW, Cox BJ, Sareen J (2009). Comorbidity of Axis I and II mental disorders with schizophrenia and psychotic disorders: findings from the National Epidemiologic Survey on Alcohol and Related Conditions. Canadian Journal of Psychiatry Revue Canadienne de Psychiatrie 54, 477-486.

Myin-Germeys I, Van Os J (2007). Stress-reactivity in psychosis: evidence for an affective pathway to psychosis. Clinical Psychology Review 27, 409-424.

Nimh.Genetics.Initiative (1992). Family Interview for Genetic Studies (FIGS). National Institute of Mental Health: Rockville, Md.

Philip NS, Sweet LH, Tyrka AR, Carpenter SL, Albright SE, Price LH, Carpenter LL (2016). Exposure to childhood trauma is associated with altered n-back activation and performance 
in healthy adults: implications for a commonly used working memory task. Brain Imaging Behavior 10, 124-135.

Price AL, Patterson NJ, Plenge RM, Weinblatt ME, Shadick NA, Reich D (2006). Principal components analysis corrects for stratification in genome-wide association studies. Nature Genetics 38, 904-909.

International Schizophrenia C, Purcell SM, Wray NR, Stone JL, Visscher PM, O'donovan MC, Sullivan PF, Sklar P (2009). Common polygenic variation contributes to risk of schizophrenia and bipolar disorder. Nature $\mathbf{4 6 0}$, 748-752.

Sahu G, Malavade K, Jacob T (2016). Cognitive impairment in Schizophrenia: interplay of BDNF and childhood trauma? A review of literature. Psychiatric Quarterly 87, 559-569.

Schizophrenia Working Group of the Psychiatric Genomics C (2014). Biological insights from 108 schizophrenia-associated genetic loci. Nature 511, 421-427.

Selten JP, Sijben NE, Van Den Bosch RJ, Omloo Visser J, Warmerdam H (1993). The subjective experience of negative symptoms: a self-rating scale. Comprehensive Psychiatry 34, 192-197.

Sieradzka D, Power RA, Freeman D, Cardno AG, Mcguire P, Plomin R, Meaburn EL, Dudbridge F, Ronald A (2014). Are genetic risk factors for psychosis also associated with dimension-specific psychotic experiences in adolescence? PLOS ONE 9, e94398.

Slade M, Phelan M, Thornicroft G, Parkman S (1996). The Camberwell Assessment of Need (CAN): comparison of assessments by staff and patients of the needs of the severely mentally ill. Social Psychiatry and Psychiatric Epidemiology 31, 109-113.

Statacorp (2015). STATA Statistical Software: Release 14. College Station: Texas.

Steinberg S, De Jong S, Andreassen OA, Werge T, Borglum AD, Mors O, Mortensen PB, Gustafsson O, Costas J, Pietilainen OP, Demontis D, Papiol S, Huttenlocher J, Mattheisen M, Breuer R, Vassos E, Giegling I, Fraser G, Walker N, Tuulio-Henriksson A, Suvisaari J, Lonnqvist J, Paunio T, Agartz I, Melle I, Djurovic S, Strengman E, G.R. O.U.P., Jurgens G, Glenthoj B, Terenius L, Hougaard DM, Orntoft T, Wiuf C, Didriksen M, Hollegaard MV, Nordentoft M, Van Winkel R, Kenis G, Abramova L, Kaleda V, Arrojo M, Sanjuan J, Arango C, Sperling S, Rossner M, Ribolsi M, Magni V, Siracusano A, Christiansen C, Kiemeney LA, Veldink J, Van Den Berg L, Ingason A, Muglia P, Murray R, Nothen MM, Sigurdsson E, Petursson H, Thorsteinsdottir U, Kong A, Rubino IA, De Hert M, Rethelyi JM, Bitter I, Jonsson EG, Golimbet V, Carracedo A, Ehrenreich $\mathrm{H}$, Craddock N, Owen MJ, O'donovan MC, Ruggeri M, Tosato S, Peltonen L, Ophoff RA, Collier DA, St Clair D, Rietschel M, Cichon S, Stefansson H, Rujescu D, Stefansson K (2011). Common variants at VRK2 and TCF4 conferring risk of schizophrenia. Human Molecular Genetics 20, 4076-4081.

Stochl J, Khandaker GM, Lewis G, Perez J, Goodyer IM, Zammit S, Sullivan S, Croudace TJ, Jones PB (2015). Mood, anxiety and psychotic phenomena measure a common psychopathological factor. Psychological Medicine 45, 1483-1493.
Svrakic DM, Zorumski CF, Svrakic NM, Zwir I, Cloninger CR (2013). Risk architecture of schizophrenia: the role of epigenetics. Current Opinion in Psychiatry 26, 188-195.

Toulopoulou T, Picchioni M, Rijsdijk F, Hua-Hall M, Ettinger U, Sham P, Murray R (2007). Substantial genetic overlap between neurocognition and schizophrenia: genetic modeling in twin samples. Archives of General Psychiatry 64, 1348-1355.

Tsuang MT, Dempsey GM (1979). Long-term outcome of major psychoses. II. Schizoaffective disorder compared with schizophrenia, affective disorders, and a surgical control group. Archives of General Psychiatry 36, 1302-1304.

Van Nierop M, Viechtbauer W, Gunther N, Van Zelst C, De Graaf R, Ten Have M, Van Dorsselaer S, Bak M, Genetic R, Investigators OUOP, Van Winkel R (2015). Childhood trauma is associated with a specific admixture of affective, anxiety, and psychosis symptoms cutting across traditional diagnostic boundaries. Psychological Medicine 45, 1277-1288.

Van Os J (2016). Measures of psychosis proneness and genetic risk for schizophrenia. JAMA Psychiatry 73, 638.

Van Os J, Kenis G, Rutten BP (2010). The environment and schizophrenia. Nature 468, 203-212.

Van Os J, Marsman A, Van Dam D, Simons CJ, Investigators G (2017). Evidence that the impact of childhood Trauma on IQ is substantial in controls, moderate in siblings, and absent in patients with psychotic disorder. Schizophrenia Bulletin. doi: 10.1093/schbul/sbw177. [Epub ahead of print].

Van Os J, Reininghaus U (2016). Psychosis as a transdiagnostic and extended phenotype in the general population. World Psychiatry 15, 118-124.

Van Rossum I, Dominguez MD, Lieb R, Wittchen HU, Van Os J (2011). Affective dysregulation and reality distortion: a 10 -year prospective study of their association and clinical relevance. Schizophrenia Bulletin 37, 561-571.

Varghese D, Scott J, Welham J, Bor W, Najman J, O'callaghan M, Williams G, Mcgrath J (2011).

Psychotic-like experiences in major depression and anxiety disorders: a population-based survey in young adults. Schizophrenia Bulletin 37, 389-393.

Velthorst E, Levine SZ, Henquet C, De Haan L, Van Os J, Myin-Germeys I, Reichenberg A (2013). To cut a short test even shorter: reliability and validity of a brief assessment of intellectual ability in schizophrenia-a control-case family study. Cognitive Neuropsychiatry 18, 574-593.

Verdoux H, Van Os J, Maurice-Tison S, Gay B, Salamon R, Bourgeois M-L (1999). Increased occurrence of depression in psychosis-prone subjects: A follow-up study in primary care settings. Comprehensive Psychiatry 40, 462-468.

Vollema MG, Ormel J (2000). The reliability of the structured interview for schizotypy-revised. Schizophrenia Bulletin 26, 619-629.

Wechsler D (1997). WAIS-III: Wechsler Adult Intelligence Scale (3rd ed.) Administration and Scoring Manual. Psychological Corporation: San Antonio, TX.

Wigman JT, Van Nierop M, Vollebergh WA, Lieb R, Beesdo-Baum K, Wittchen HU, Van Os J (2012). Evidence that psychotic symptoms are prevalent in disorders of anxiety and depression, impacting on illness onset, risk, and severity-implications for diagnosis and ultra-high risk research. Schizophrenia Bulletin 38, 247-257. 
Wing JK, Babor T, Brugha T, Burke J, Cooper JE, Giel R, Jablenski A, Regier D, Sartorius N (1990). SCAN. Schedules for clinical assessment in neuropsychiatry. Archives of General Psychiatry 47, 589-593.

Wing JK, Cooper JE, Sartorius N (1974). The Measurement and Classification of Psychiatric Symptoms. Cambridge University Press: London.

World Health Organisation (1992). WHO Coordinated Multi-Centre Study on the Course and Outcome of Schizophrenia. World Health Organisation: Geneva.

Zammit S, Hamshere M, Dwyer S, Georgiva L, Timpson N, Moskvina V, Richards A, Evans DM, Lewis G, Jones P, Owen MJ, O'donovan MC (2014). A population-based study of genetic variation and psychotic experiences in adolescents. Schizophrenia Bulletin 40, 1254-1262.

\section{Appendix}

\section{GROUP Investigators}

GROUP investigators are: Berhooz Z. Alizadeh ${ }^{\mathrm{a}}$, Agna A. Bartels-Velthuis ${ }^{\mathrm{a}}$, Nico J. van Beveren ${ }^{\mathrm{b}, \mathrm{c}, \mathrm{d}}$, Richard Bruggeman $^{\mathrm{a}}$, Wiepke Cahn ${ }^{\mathrm{e}}$, Lieuwe de Haan ${ }^{\mathrm{f}}$, Philippe Delespaul $^{\mathrm{g}}$, Carin J. Meijer, Inez Myin-Germeys ${ }^{\mathrm{h}}$, Rene S. Kahn ${ }^{\mathrm{e}}$, Frederike Schirmbeck ${ }^{\mathrm{f}}$, Claudia J.P.
Simons ${ }^{\mathrm{g}, \mathrm{i}}$, Neeltje E. van Haren ${ }^{\mathrm{e}}$, Jim van Os ${ }^{\mathrm{g}, \mathrm{j}}$, Ruud van Winkelg,h

${ }^{a}$ University of Groningen, University Medical Center Groningen, University Center for Psychiatry, Groningen, The Netherlands; ${ }^{\mathrm{b}}$ Antes Center for Mental Health Care, Rotterdam, The Netherlands; ${ }^{\mathrm{C}}$ Erasmus MC, Department of Psychiatry, Rotterdam, The Netherlands; ${ }^{\mathrm{d}}$ Erasmus MC, Department of Neuroscience, Rotterdam, The Netherlands; 'University Medical Center Utrecht, Department of Psychiatry, Brain Center Rudolf Magnus, Utrecht, The Netherlands; ${ }^{\mathrm{f}}$ Academic Medical Center, University of Amsterdam, Department of Psychiatry, Amsterdam, The Netherlands; ${ }^{g}$ Maastricht University Medical Center, Department of Psychiatry and Psychology, School for Mental Health and Neuroscience, Maastricht, The Netherlands; ${ }^{\mathrm{h}} \mathrm{KU}$ Leuven, Department of Neuroscience, Research Group Psychiatry, Center for Contextual Psychiatry, Leuven, Belgium; ${ }^{i}$ GGzE, Institute for Mental Health Care Eindhoven and De Kempen, Eindhoven, The Netherlands; 'King's College London, King's Health Partners, Department of Psychosis Studies, Institute of Psychiatry, London, UK 